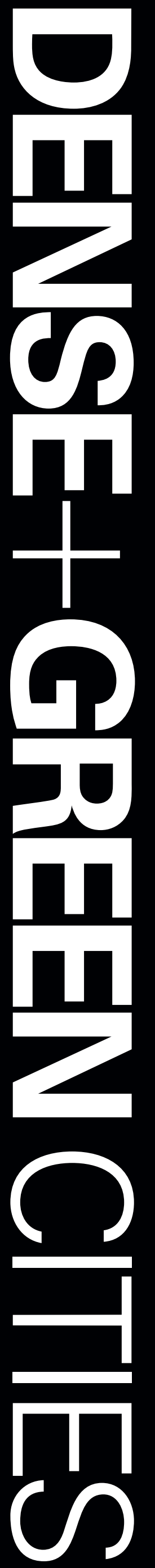


Dense+Green Cities

Architecture as

Urban Ecosystem
Foreword by

Peter G. Rowe

Raymond Garbe Professor of Architecture and Urban Design and Harvard University

Distinguished Service Professor

\section{Contributions by}

Peter Edwards

Christophe Girot

Sacha Menz
Birkhäuser

Basel

\author{
Researchers \\ Michelle Jiang Yingying \\ (Coordinator) \\ Richard Belcher \\ Peter Christensen \\ Emek Erdolu \\ Srilalitha Gopalakrishnan \\ Mayank Kaushal \\ Thibault Pilsudski \\ Prashanth Raju \\ Ester Suen Yun Ju \\ Jonathan Tan Koon Ngee
}




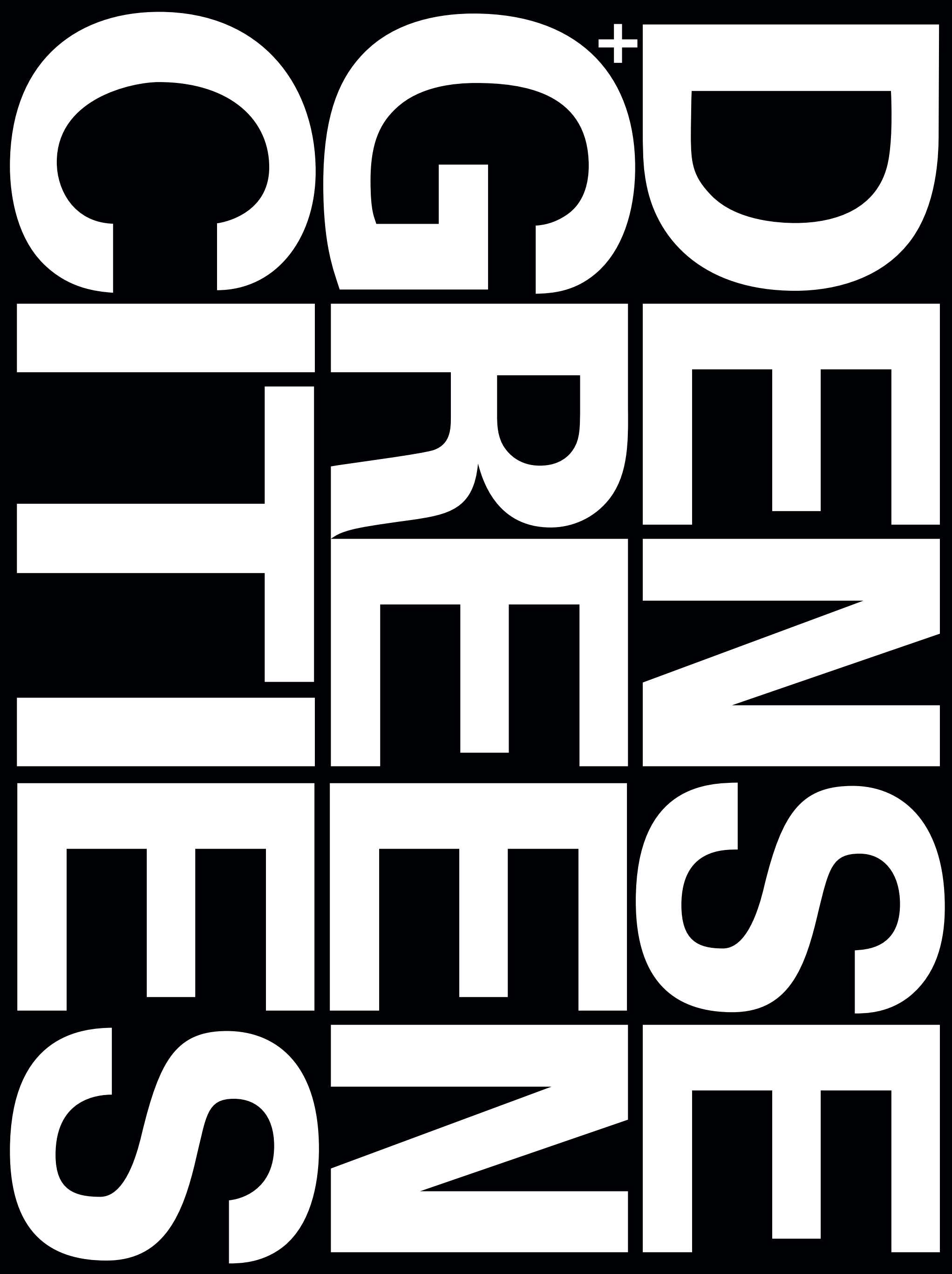


Layout, cover design and typography

Waterhouse Cifuentes Design

Cover photograph

Iwan Baan

Copyediting

Elizabeth Kugler

Editor for the Publisher

Andreas Müller

Production

Heike Strempel

Paper

$135 \mathrm{~g} / \mathrm{m}^{2}$ Condat matt Perigord

Printing

Grafisches Centrum Cuno GmbH \& Co. KG
We would like to thank the Singapore-ETH Centre Future Cities Laboratory as well as ETH Zurich and the Singapore University of Technology and Design for their generous support of this publication.

Bibliographic information published by the German National Library:

The German National Library lists this publication in the Deutsche Nationalbibliografie.

Detailed bibliographic data are available on the Internet at http://dnb.dnb.de.

Library of Congress Control Number: 2019952517

This work is subject to copyright. All rights are reserved, whether the whole or part of the material is concerned, specifically the rights of translation, reprinting, re-use of illustrations, recitation, broadcasting, reproduction on microfilms or in other ways, and storage in databases. For any kind of use, permission of the copyright owner must be obtained.

This publication is also available as an e-book (ISBN PDF 978-3-0356-1511-1).

() 2020 Birkhäuser Verlag GmbH, Basel

P.O. Box 44, 4009 Basel, Switzerland

Part of Walter de Gruyter GmbH, Berlin/Boston

Printed on acid-free paper produced from chlorine-free pulp.

TCF $\infty$

Printed in Germany

ISBN 978-3-0356-1531-9

987654321

www.birkhauser.com 